\title{
ACVR1 mutation and Fibrodysplasia Ossificans Progressiva in Chinese children
}

\author{
Assunta $\mathrm{CH} \mathrm{Ho}^{1 *}$, Joannie Hui ${ }^{1}, \mathrm{KH}$ Chan ${ }^{2}, \mathrm{KL} \mathrm{Liu}^{3}$, Bobby KW Ng${ }^{3}$, Ivan FM Lo ${ }^{2}$, STS Lam² \\ From 18th Pediatric Rheumatology European Society (PReS) Congress \\ Bruges, Belgium. 14-18 September 2011
}

\section{Introduction}

Fibrodysplasia Ossificans Progressiva (FOP) is a rare autosomal dominant connective tissue disorder characterized by congenital great toes malformation and progressive heterotopic osteogenesis leading to progressive debilitating ankylosis of the body. A recurrent missense mutation in the activin receptor $1 \mathrm{~A}$ /activin-like kinase 2 (ACVR1/ALK2), a bone morphogenetic protein (BMP) receptor, was identified in almost all FOP patients ${ }^{1}$. Here we report two unrelated Chinese FOP adolescents harbouring this mutation. Both were referred to the rheumatological service with joint stiffness and abnormal calcification on imaging.

\section{Case 1}

CSNM developed progressive jaw ankylosis since twelve years of age. She started to have recurrent soft tissue swellings involving neck, shoulders and back at sixteen. At that time she was suffering from pulmonary tubercu-
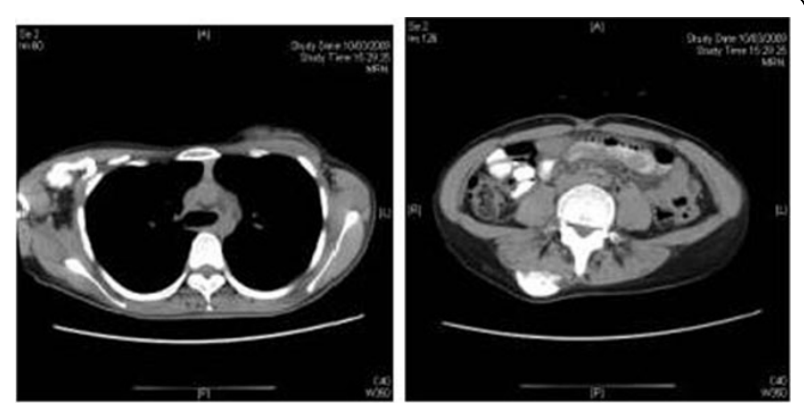

Fig 1 CT images of case 1- extraosseous ossification

\footnotetext{
* Correspondence: assuntaho@cuhk.edu.hk

${ }^{1}$ Department of Pediatrics, Prince of Wales Hospital, Chinese University of Hong Kong, Hong Kong SAR, Hong Kong

Full list of author information is available at the end of the article
}

losis. The swellings subsided spontaneously, leaving bony hard masses.

\section{Case 2}

WCY was born with multiple congenital abnormalities including hypospadias, atrial septal defect (ASD) and multiple exostoses. Starting from twelve year of age, he developed ankylosis of the left temporomandibular joint. The first FOP flare started with a painful swelling over his back and neck. This was followed by stiffening of the muscles.

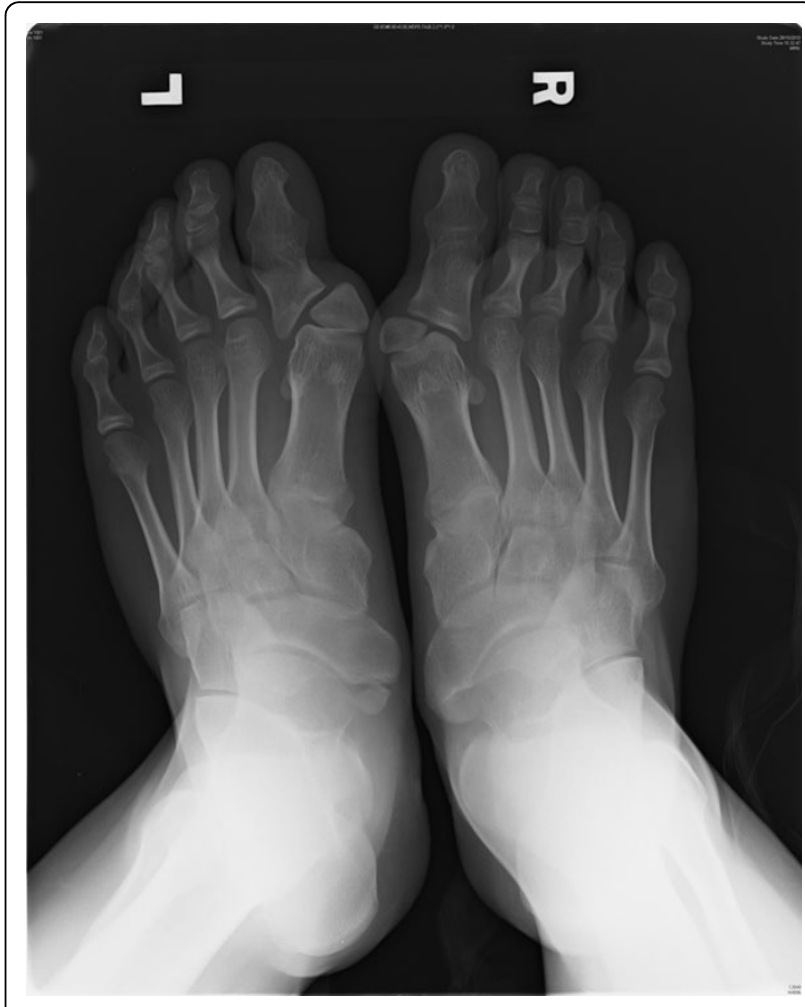

Fig 2 great toe abnormality of case 2 
Both patients had a heterozygous c.617G >A mutation detected in the exon 7 of the ACVR1 gene, resulting in an Arg206His substitution.

\section{Conclusion}

Confirmation of the diagnosis of FOP is relatively more straightforward now with the availability of molecular genetic testing. A high index of suspicion is the key to diagnose these patients early with unexplained recurrent ossified swellings and congenital feet abnormalities. Unnecessary and often harmful biopsy procedures could be avoided during the diagnostic workup of these patients.

\section{Author details}

${ }^{1}$ Department of Pediatrics, Prince of Wales Hospital, Chinese University of Hong Kong, Hong Kong SAR, Hong Kong. ${ }^{2}$ Clinical Genetic Service, Department of Health, Hong Kong SAR, Hong Kong. ${ }^{3}$ Department of Orthopedics and Traumatology, Prince of Wales Hospital, Chinese University of Hong Kong, Hong Kong SAR, Hong Kong.

Published: 14 September 2011

\section{Reference}

1. Shore EM, Xu M, Feldman GJ, et al: A recurrent mutation in the BMP type I receptor ACVR1 causes inherited and sporadic fibrodysplasia ossificans progressive. Nat Genet 2006, 28:525-527.

doi:10.1186/1546-0096-9-S1-P30

Cite this article as: Ho et al:: ACVR1 mutation and Fibrodysplasia

Ossificans Progressiva in Chinese children. Pediatric Rheumatology 20119

(Suppl 1):P30.
Submit your next manuscript to BioMed Central and take full advantage of:

- Convenient online submission

- Thorough peer review

- No space constraints or color figure charges

- Immediate publication on acceptance

- Inclusion in PubMed, CAS, Scopus and Google Scholar

- Research which is freely available for redistribution

Submit your manuscript at www.biomedcentral.com/submit 